\title{
GAP-43 Transgenic Mice: Dispersed Genomic Sequences Confer a GAP-43-like Expression Pattern during Development and Regeneration
}

\author{
Jens Vanselow, ${ }^{a}$ Ed Grabczyk, Jiang Ping, Manfred Baetscher, ${ }^{\mathrm{b}}$ Sally Teng, and Mark C. Fishman \\ Developmental Biology Laboratory, Massachusetts General Hospital and Department of Medicine, Harvard Medical \\ School, Boston, Massachusetts 02115
}

\begin{abstract}
Using transgenic mice, we have examined the expression pattern conferred by regions of genomic GAP. 43 coupled to $\beta$-galactosidase. We demonstrate that gene constructions that include the GAP-43 5 '-flanking region along with sufficient sequences of the first intron drive $\beta$-galactosidase (lac $Z$ ) expression to mimic in many regards the complex spatial and temporal pattern of endogenous GAP-43 expression. Transgene expression reaches peak levels during development, and persists at high levels in particular adult brain regions, such as the hippocampus and olfactory bulb. The inclusion of a stretch of the first intron in the construction is necessary to prevent expression outside of the nervous system, indicating that some of the cell specificity of GAP-43 expression is due to suppression of expression in inappropriate tissues. Injury caused by sciatic nerve crush causes reexpression of the transgene in adult sensory and motor neurons. This genomic region of GAP-43, therefore, includes elements responsive to neuronal growth signals that regulate both development and regeneration.

[Key words: GAP-43, neuromodulin, transgenic mice, regeneration, development, intron]
\end{abstract}

Prominent nerve cell growth occurs during developmental and regenerative axonogenesis. More subtle and focal growth accompanies certain types of long-term memory consolidation (Bailey and Chen, 1988). Orchestrated patterns of gene expression are likely to coordinate these types of nerve cell growth, but the molecular basis of such genomic control remains unclear.

GAP-43 was first suggested as an underpinning of axonal growth by dint of its high level expression during development and regeneration (Skene and Willard, $1981 \mathrm{a}, \mathrm{b}$ ). With rare exceptions, it is expressed strictly in neurons. During development, GAP-43 is first expressed after neuroblasts have ceased mitosis, when they are extending their processes (Biffo et al., 1990). For most neurons expression peaks in the perinatal period and then recedes. High-level expression persists in the adult in certain regions, such as the entorhinal cortex, the hippocam-

\footnotetext{
Received Feb. 15, 1993; revised June 14, 1993; accepted Aug, 9, 1993

This study was supported in part by a grant from the Sumitomo Chemical and Pharmaceutical Cos. to M.C.F. J.V. was supported by a Postdoktorander-Stipendium from Boehringer Ingelheim Fonds.

Correspondence should be addressed to Dr. Mark C. Fishman, Developmental Biology Laboratory, 149 13th Street, 4th floor, Charlestown, MA 02129.

Present address: FBN, Wilhelm-Stahl-Allee 2, 0-255I Dummerstorf, Germany.

'Present address: Bio Transplant, Inc., 96 13th Street, Charlestown, MA 02129. Copyright (C) 1994 Society for Neuroscience 0270-6474/94/140499-12\$05.00/0
}

pus, the olfactory bulb, and the association cortices. This has been linked speculatively to the continued plasticity of these structures in the adult (Benowitz et al., 1988; De la Monte et al., 1989). Other work has suggested roles for this protein in long-term potentiation (Lovinger et al., 1985), as well as in transduction of signals at the growth cone and synapse (Alexander et al., 1987; De Graan et al., 1988; Dekker et al., 1989; Strittmatter et al., 1990).

GAP-43 is highly regulated at the level of gene expression. High GAP-43 levels, assessed by in situ hybridization or Northern blot, are present during development, in the adult regions where expression persists, and during regeneration (Neve et al., 1987; Rosenthal et al., 1987; Hoffman, 1989; Bendotti et al., 1991; Fitzgerald et al., 1991), although it is not clear how much of this regulation is transcriptional. In vivo, transcriptional control of GAP-43, during both development and regeneration, has been documented by nuclear run-on assays (Basi et al., 1987). In cell culture, glucocorticoid suppression of GAP-43 mRNA expression has been shown to be at the level of transcription, while induction by NGF appears to be posttranscriptional (Federoff et al., 1988; Perrone-Bizzozero et al., 1993).

Since growth regulation is a complex process, with multiple cell-autonomous and extrinsic controls best evaluated in the intact animal, we have begun the dissection of the regulatory regions of the GAP-43 gene in transgenic mice. Our results demonstrate that constructions including the 5 '-flanking sequences and sufficient portions of the first intron largely mimic natural GAP-43 expression. Furthermore, this region of the GAP-43 gene also includes elements that enhance expression in injured nerves.

\section{Materials and Methods}

Plasmid construction. All cloning steps were carried out in the plasmid vector pSP72 (Promega). To facilitate the isolation of the constructions from the vector, NotI and Sfil restriction sites were introduced outside the XhoI and BglII sites that flank the polylinker. Constructions that included the first exon (10E4, 6E 1 1, 6E 0.2, 1.6E 2, 1.6E4) were designed to splice to give polycistronic messages (Kozak, 1986b, 1987). Analogous splicing constructions containing the bacterial chloramphenicol acetyl transferase gene have been tested in vitro (E. Grabczyk, A. Pack, and $M$. C. Fishman, unpublished observations). To achieve this, the bacterial lacZ gene cassette (BamH1/HindIII) was excised from pCHIIO (Pharmacia) and inserted into pSP72Not (BgllI/HindIII). Bacterial sequences in the $5^{\prime}$ end of the lacZ cassette were then excised (HindIII/ KpnI) and replaced with an 88 base pair (bp) oligonucleotide: AGCTTAAGTGAGTAAGTGAGTAAGTGACATTTGCTTCTGTCACAACTGTGTTTCACTTACAACCTCCAAACAGACACCACCATGGTAC that contained tandem translation stop signals in each reading frame and a favorable eukaryotic translation initiation site (Kozak, 1986a). 


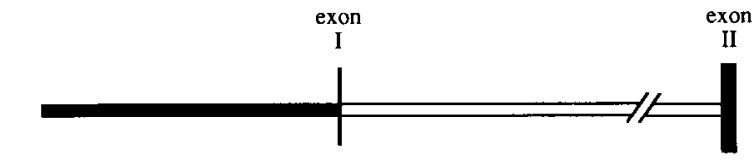

1.6

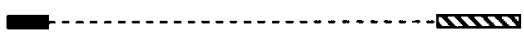

$6 \mathrm{E} 0.2$

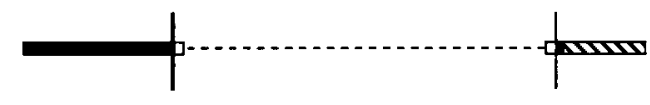

$1.6 \mathrm{E} 4$

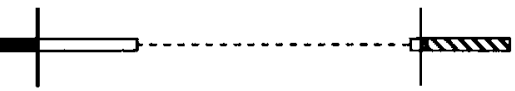

$10 \mathrm{E} 4$

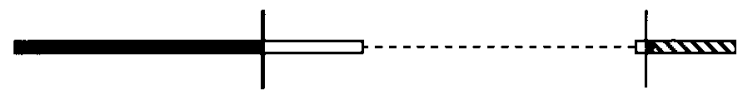

$6 \mathrm{E} 11$

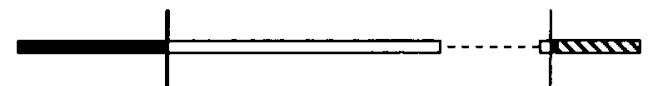

$1.6 \mathrm{E} 12$

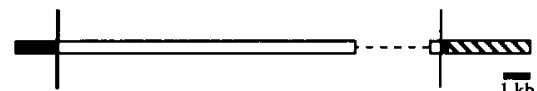

Figure 1. Structure of the GAP-43/lacZ fusion genes. Schematic representations of the constructions used to generate the transgenic mice are aligned below a representation of the region of the first two exons of the GAP-43 gene. Exon I and the beginning of exon II are indicated as black vertical boxes, and the 5 -flanking region as a thick black line. The dashed lines in the constructions indicate junction points that have been separated here diagrammatically in order to make clear the linear relationship between the different constructions and the gene. The five constructions with introns all contain the $220 \mathrm{bp}$ of the first intron that is adjacent to the second exon (white box), 22 bp of exon II (thin vertical har), and an 88 bp sequence (gray shading) with multiple translation stop signals $5^{\prime}$ of the lacZ gene (hatching). Construction 1.6 contains GAP-43 5'-flanking sequences fused to the lac $Z$ gene at the initiating ATG. All known and postulated transcription start sites and promoter sequences are included within $1.6 \mathrm{~kb}$ of $5^{\prime}$ flanking sequence, and therefore are included in all constructs.

All constructions that included portions of intron I also contained the splice acceptor sequence from the second exon of the GAP-43 gene (Grabczyk et al., 1990). This sequence is included in a $220 \mathrm{bp}$ fragment (SstI/AvaII) of the GAP-43 gene that was excised from splicing construction precursor 72gavacat (Grabczyk, Pack, and Fishman, unpublished observations) and was cloned upstream of the $88 \mathrm{bp}$ oligonucleotide (HindIII). This step regenerated the pSP72 polylinker from SstI to HindIII. Constructions $10 \mathrm{E} 4,6 \mathrm{E} 11$, and $1.6 \mathrm{E} 12$ were obtained by inserting the genomic clones $10 \mathrm{R} 1 \mathrm{X} 4,6 \mathrm{R} 1 \mathrm{X} 10$, and $1.5 \mathrm{R} 1 \mathrm{X} 12$ (Grabczyk et al., 1990) upstream of the splice acceptor sequence in Sall of the polylinker. Construction $6 \mathrm{E} 0.2$ was made by deleting the intron sequence from NaeI $[+0.2$ kilobase $(\mathrm{kb})]$ to SalI $(+11 \mathrm{~kb})$ from construction $6 \mathrm{E} 11$. To obtain construction $1.6 \mathrm{E} 4$, a $5.6 \mathrm{~kb}$ Sall/Sst $\mathrm{frag}$ ment was subcloned from the genomic clone 1.5R $1 \times 12$ (Grabczyk et al., 1990) and inserted upstream of the splice acceptor sequence (SalI/ SstI). For construction 1.6, a single base pair change introduced by oligonucleotide directed mutagenesis downstream of the GAP-43 ATG created an NcoI restriction site (Grabczyk, Pack, and Fishman, unpublished observations). This new restriction site was used to obtain a 1.6 $\mathrm{kb}$ Sall/NcoI fragment $(-1.6$ to +1$)$. The fragment was subsequently fused to the Ncol site at the new lacZ ATG.

Transgenic mice. To isolate the fusion gene for microinjections, the DNA was digested with Notl or Sfil. After electrophoretic separation in $0.8 \%$ agarose, the appropriate fragment in gel was dissolved in saturated Na-perchlorate $\left(1 \mathrm{hr}\right.$ at $\left.37^{\circ} \mathrm{C}\right)$, and isolated in a glass filter $(\mathrm{Gcl}-$ man Sciences Inc., Ann Arbor, MI). Transgenic mice (from strain B6D2F1/J; Jackson Laboratories, Bar Harbor, ME) were generated essentially as described in Hogan et al. (1986), and as is standard in this laboratory (Baetscher et al., 1991). Briefly, purified DNA $(1-2 \mu \mathrm{g} / \mathrm{ml}$ in $5 \mathrm{~mm}$ Tris, $0.1 \mathrm{~mm}$ EDTA, pH 7.4) was microinjected into the male or female pronucleus of fertilized eggs (14-20 hr after fertilization). Subsequently, the eggs were incubated overnight at $37^{\circ} \mathrm{C}, 5 \% \mathrm{CO}_{2}$ in $\mathrm{M} 16$ medium (Hogan et al., 1986). Eggs that had developed to the two-cell stage were reimplanted in $12 \mathrm{hr}$ pseudopregnant foster mothers. The resultant animals are referred to as founders, or $F_{0}$ generation. Tail biopsy-derived DNA was used for screening of the animals.

Histochemistry. $\beta$-Galactosidase histochemistry was performed according to Turner and Cepko (1987). Embryos up to day 13.5 (E13.5) were fixed by immersion in PFA ( $2 \%$ paraformaldehyde, $2 \mathrm{~mm} \mathrm{MgCl}_{2}$, $1.25 \mathrm{~mm}$ EDTA in $0.1 \mathrm{M}$ PIPES, pH 6.9) and stained for $\beta$-galactosidase activity as whole-mounts. Tissues of older embryos, and postnatal animals up to day 7 (P7), were fixed by immersion and cryostat sectioned prior to histochemistry. Animals older than P7 were perfused with phosphate-buffered saline (PBS, pH 7.4) followed by $2 \%$ PFA in deep anesthesia $(0.04 \mathrm{ml}$ of $2 \%$ Avertin per gram of body weight). Prior to sectioning, the tissue was cryoprotected in 30\% sucrose (in PBS with 2 $\mathrm{mm} \mathrm{MgCl}_{2}$ ) for $12 \mathrm{hr}$. Before staining, the cryostat scctions or wholemounts were rinsed for 10-50 min in PBS (with $2 \mathrm{mM} \mathrm{MgCl}_{2}$ ) followed by PBS with $2 \mathrm{mM} \mathrm{MgCl}$ and detergents $(00.1 \%$ sodium desoxycholate, $0.02 \% \mathrm{NP} 40$ ). Routinely, X-Gal staining was performed for $14-16 \mathrm{hr}$ overnight at $37^{\circ} \mathrm{C}$ in $1 \mathrm{mg} / \mathrm{ml}$ 5-bromo-4-chloro-3-indolyl $\beta$-D-galactopyranoside, $5 \mathrm{~mm} \mathrm{~K}_{3} \mathrm{Fe}(\mathrm{CN})_{6}, 5 \mathrm{~mm} \mathrm{~K}_{4} \mathrm{Fe}(\mathrm{CN})_{6} 3 \mathrm{H}_{2} \mathrm{O}, 2 \mathrm{~mm} \mathrm{MgCl}$, $0.01 \%$ sodium desoxycholate, $0.02 \%$ NP40 in PBS.

Surgery. For regeneration studies, the animals ( 8 weeks and older) were anesthetized with $2 \%$ Avertin $(0.02 \mathrm{ml} / \mathrm{gm}$ body weight). The left sciatic nerve was exposed after a small cut in the skin and underlying muscle tissue. Subsequently the nerve was crushed twice for $15 \mathrm{sec}$ with a small forceps. Muscles and skin were sutured and the animals were allowed to recover. At various times after the operation, the animals were anesthetized and perfusion fixed. Lumbar and posterior thoracic segments of the spinal column were dissected and processed for cryostat sectioning and X-Gal staining, as described above

$R$ Nase protection. A probe corresponding to the spliced product of the GAP-43/ $\beta$-galactosidase fusion gene from 50 bases 5 ' of the GAP43 ATG to 330 bases 3 ' was produced by polymerase chain reaction (PCR). A plasmid containing the GAP-43 cDNA that was digested with Avall, which cuts 22 bp downstream of the GAP-43 first splice junction, a region shared with the $\beta$-galactosidase construct precursor plasmid linearized with SacI (upstream of the splice acceptor). The two plasmids were mixed with two oligonucleotides, G-50Bam (CCCCGGATCCGAGAGGAGGAAAGGAGAGAAGG) and b380Eco (CCCCGAATTCCCTCTTCGCTATTACGCCAG), and PCR was performed to zip the pieces together. The products were digested with BamHI/EcoRI and a $380 \mathrm{bp}$ fragment was gel purified and subcloned into pSP72 from EcoRI to BamH1. The final clone GAP/b380 was sequenced to be sure that no point mutations were introduced.

Total cellular RNA was isolated from brain, skin, and liver of newborn transgenic and normal mice by $\mathrm{CsCl}$ ultracentrifugation after tissue disruption in guanidinium isothiocyanate. PolyA + RNA was isolated from $500 \mu \mathrm{g}$ of total RNA with the PolyATtract kit (Promega). The probe was synthesized from the T7 promoter of clone $\mathrm{GAP} / \mathrm{b} 380$ and RNase protections were performed as described previously (Grabczyk et al., 1990).

\section{Results}

5'-Flanking and intron regions are needed for neuron-specific expression

The GAP-43 gene is encoded in three exons, and has two long introns (Grabczyk et al., 1990). RNase protection and primer extension indicate transcriptional initiation to be from several 5 ' sites, the most prominent at 52 bases from the initiation ATG (Grabczyk et al., 1990). One report suggests predominant use of one site at about -460 (Nedevi et al., 1992). The constructions used, as shown in Figure 1, all included at least $1.6 \mathrm{~kb} 5^{\prime}$ of the initiating ATG and therefore included all proposed major and minor start sites. Pilot experiments, with examination of $F_{0}$ animals, revealed that $1.6 \mathrm{kh}$ of 5 '-flanking sequence does cause neuronal expression of the transgene, but that this genomic region is insufficient to restrict expression to neurons. As shown in Table 1, constructs with $1.6 \mathrm{~kb} 5$ of GAP-43 are expressed in many non-neuronal tissues. In fact, even up to $6 \mathrm{~kb}$ of $5^{\prime}$ flanking region is insufficient to prevent expression outside of the nervous system (Table 1). Intron-exon splice junctions can 

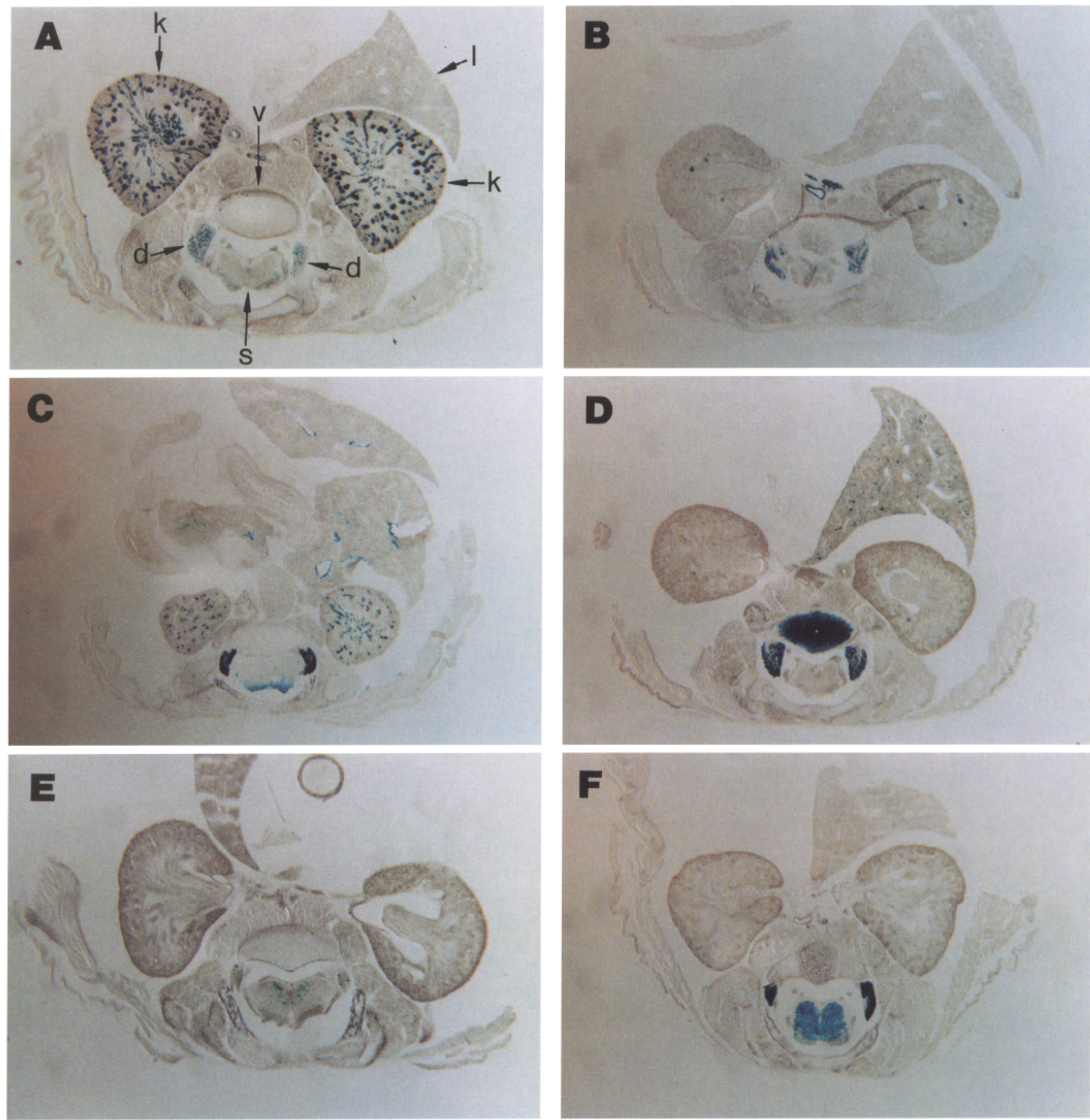

Figure 2. Expression of different transgenic constructions. Low-power views of cross sections at the level of the kidney show $\beta$-galactosidase expression in mice bearing different constructs: $A, 1.6 ; B, 6 \mathrm{E} 0.2 ; C, 1.6 \mathrm{E} 4 ; D, 10 \mathrm{E} 4 ; E, 1.6 \mathrm{E} 12 ; F, 6 \mathrm{E} 11$. The expression of $\beta$-galactosidase is restricted to neurons only in animals with $1.6 \mathrm{E} 12$ and $6 \mathrm{E} 11$ constructs $(E$ and $F)$. Animals with constructs containing less intron show both neuronal and non-neuronal expression of $\beta$-galactosidase $(A-D) . k$, kidney; $l$, liver; $v$, vertebra; $d$, dorsal root ganglia; $s$, spinal cord.

enhance expression of some transgenes (Brinster et al., 1988; Choi et al., 1991; Palmiter et al., 1991), so $\mathrm{F}_{0}$ animals were generated that bore 200 bases at the $5^{\prime}$ and $3^{\prime}$ end of intron 1 in addition to $6 \mathrm{~kb}$ of $5^{\prime}$-flanking sequence (constructs $6 \mathrm{E} 0.2$ ), but these animals also have widespread expression outside of the nervous system.

Clearly these genomic regions are insufficient to restrict expression to neurons. Analysis of the pattern within the brain itself is complicated in $\mathrm{F}_{0}$ animals because they may be chimeric. For that reason other series of transgenic animals were bred and maintained as lines. Preliminary experiments in tissue culture indicated that the first $4 \mathrm{~kb}$ of intron 1 is sufficient to confer a response to glucocorticoids (E. Grabczyk and M. C. Fishman, unpublished observations). Therefore, this region was included in several transgene constructs. Four separate lines of 1.6E4 (1.6 $\mathrm{kb} 5^{\prime}$ and $4 \mathrm{~kb}$ of intron 1) and two of 10E4 (10 kb 5' and $4 \mathrm{~kb}$ 
Table 1. Transgene expression at $\mathbf{P 0}$

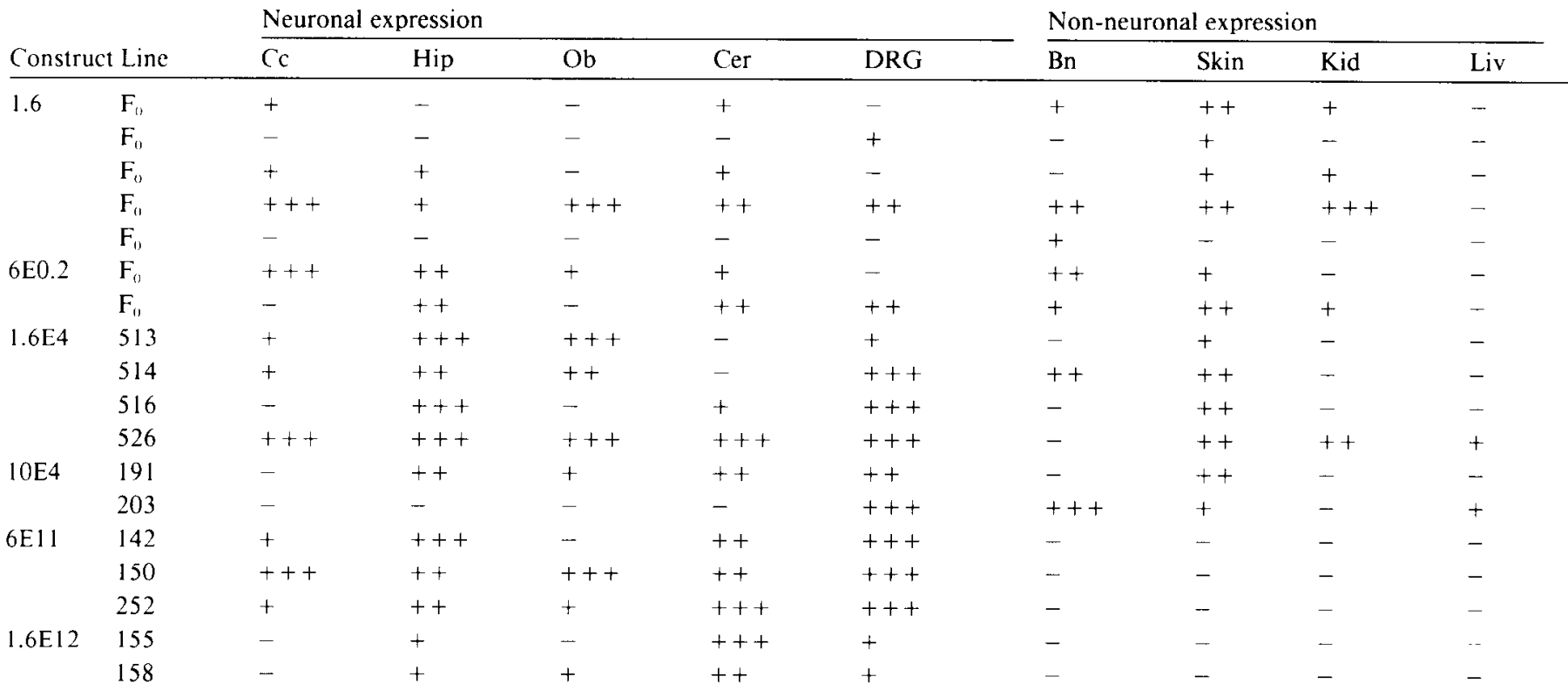

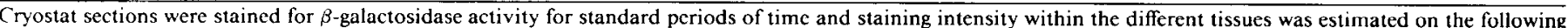

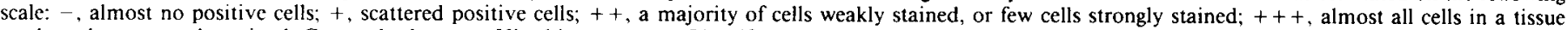

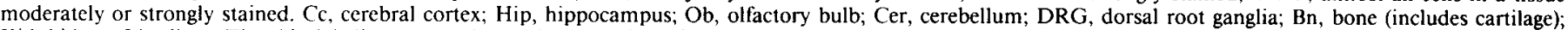

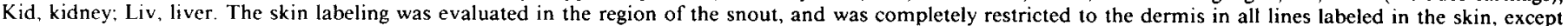
for line 516, where labeling was essentially restricted to the epidermis.

of intron 1) were generated and offspring analyzed as shown in Table 1 and illustrated in Figure 2.

In the perinatal period, these animals all express $\beta$-galactosidase in the brain. However, in all cases, they also express $\beta$-galactosidase outside of the nervous system. Examples of the patterns of non-neuronal expression in some of these lines are illustrated in Figure 2, which shows low-power cross sections of a representative animal for each construct, done at the level of the kidney. As shown, animals containing transgene constructs that lack the region of intron from 4 to $11 \mathrm{~kb}$ show $\beta$-galactosidase activity outside of the nervous system (Fig. $2 A-$ $D$ ). In all of these lines, there is expression in the nervous system, but this aspect was not pursued in detail in lines showing additional inappropriate non-neuronal expression.

Constructs with longer stretches of intron 1 more closely approximate the pattern of native GAP-43. The perinatal distribution of expression in five lines bearing two different constructions, with $11 \mathrm{~kb}$ and $12 \mathrm{~kb}$ of intron 1 , respectively, is shown in Table 1, and Figure 2, $E$ and $F$. There is no expression in any of the examined non-neuronal tissues in mice with these transgenes. Within the nervous system, expression is absent in fiber layers or fiber tracts of the brain, retina, and spinal cord, suggesting that glial cells do not express these transgenes.

There is some variability between the three 6E 11 lines, and between the two 1.6E 12 lines. As shown in Table 1, several of these lines express the transgene only in subsets of predicted GAP-43-expressing neuronal populations. However, expression is always restricted to neurons. The variability is due, in all likelihood, to the well-described chromosomal position effects upon transgene expression that has been observed for many transgenes (Al Shawi et al., 1990; Allen et al., 1990; Bonnerot et al., 1990; Tan, 1991; Weis et al., 1991). It is also certainly conceivable that, as for the globin gene cluster (Grosveld et al.,
1987; Reitman et al., 1990), additional elements, even tens of kilobases away, might enhance the ovcrall level of expression, and insulate the transgene from position effects.

Occasionally a small population of non-neuronal cells transiently expresses these transgenes in the midfacial mesenchymal tissue between the two nares at embryonic or early postnatal stages. A similar observation has been described for fusion genes using the neuron-specific promoter of the dopamine $\beta$-hydroxylase gene (Kapur el al., 1991).

RNase protection assays were carried out in order to verify that transgene expression initiates within the GAP-43 upstream region, and that it is correctly spliced. The probe used, as shown in Figure $3 A$, corresponds to the predicted correctly spliced product from the transgene, and therefore should be fully protected (except for the flanking bacterial sequences, shown as the thin black line) only if transcription initiates within the GAP. 43 promoter and is spliced accurately. Native GAP-43 transcription initiates from multiple sites (Grabczyk et al., 1990) and the $3^{\prime}$ end of this probe corresponds to the most prominent and proximal of these start sites, effectively summing all transcripts from this and more $5^{\prime}$ sites.

Expression was examined in line 150 , a $6 \mathrm{E} 11$ line with neuron-specific expression, and in line 526, a 1.6E4 line with prominent neuronal and non-neuronal expression. Native GAP-43 is revealed by the 102 base protected fragment in all samples of brain RNA (lanes 3, 6, 9, 12) in Figure $3 B$, and is clearly expressed at a much higher level than is the transgene. The fully protected fragment of 380 bases is present using RNA from the brain of line 150 mice (Fig. $3 B$, lane 3 ), but not using skin or liver RNA from this line (lanes 4,5 ). In contrast, in line 526, this fragment is protected using RNA from skin and liver (lanes 7,8 ), in addition to that from the brain (lane 6 ). The data from RNase protection cannot be compared quantitatively to that of 


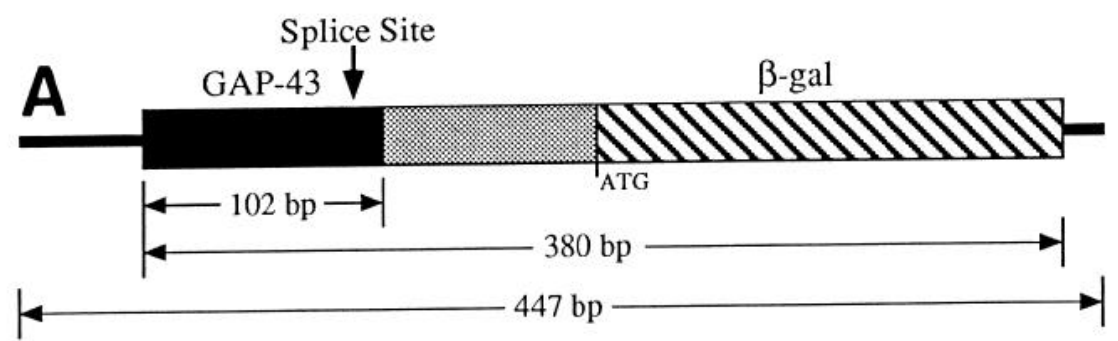

B

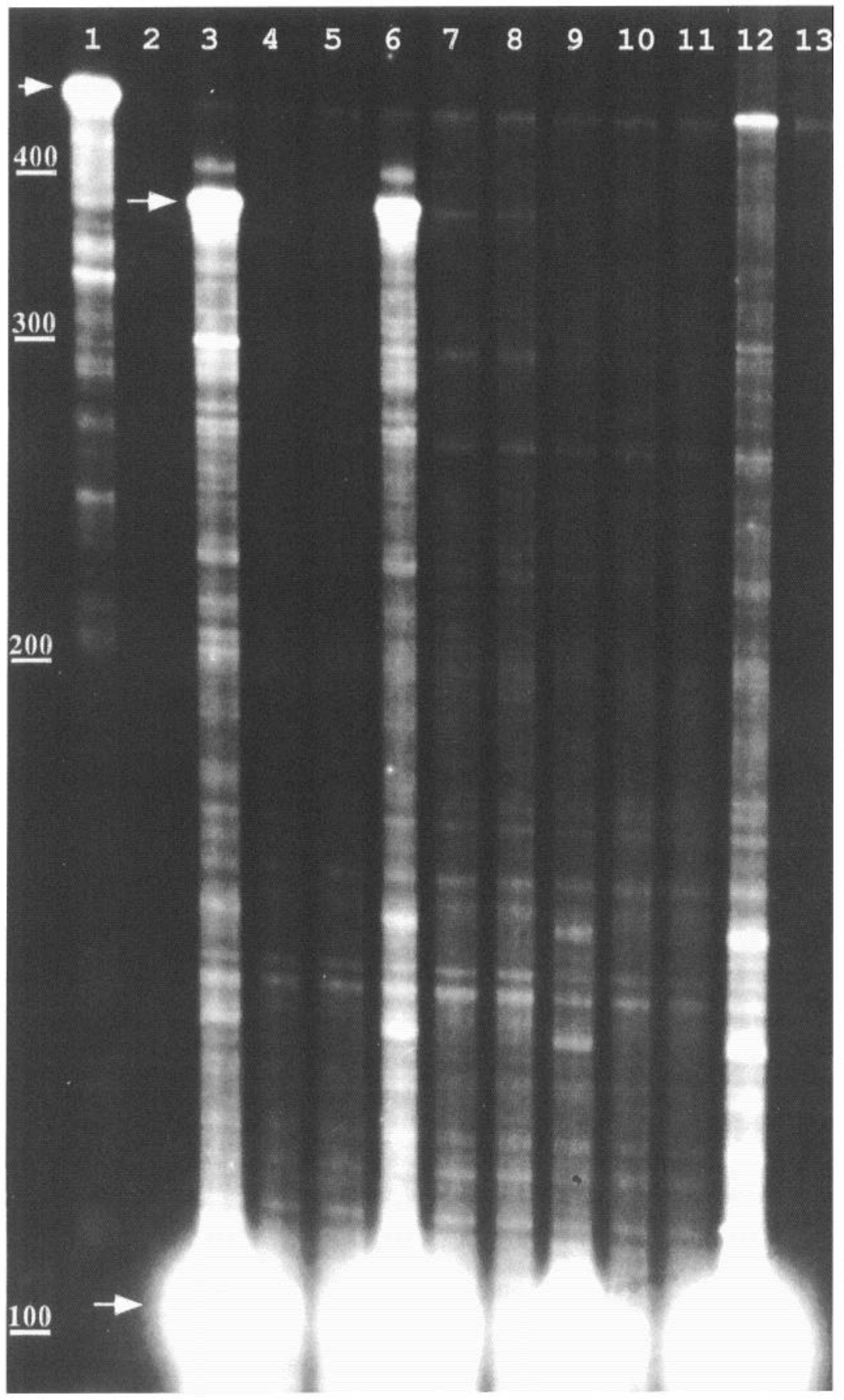

Figure 3. RNase protection of transgenic transcripts. $A$, A schematic of the probe used for RNase protections. Black, GAP-43 sequence; gray, linker; hatching, lacZ sequence; black line, plasmid sequence. $B$, PolyA + RNA from brain, skin, and liver was analyzed for line 150 (lanes 3-5), line 526 (lanes 68 ), and normal mice (lanes 9-11) using the probe indicated. For line 150, a band corresponding to the 380 base fully protected fusion probe is only present in RNA from the brain of line 150 (lane 3 , arrow), but not in skin (lane 4), or liver (lane 5). For line 526, the fully protected fragment is present in brain (lane 6), and, to a lesser extent, in the skin (lane 7) and liver (lane 8). The 102 base fragment (arrow at bottom of gel), corresponding to protection from the endogenous GAP-43 message, is present in all brain samples. Lane 1, fulllength probe (arrow); lane 2, empty; lane 12 , rat brain; lane 13, tRNA control. 


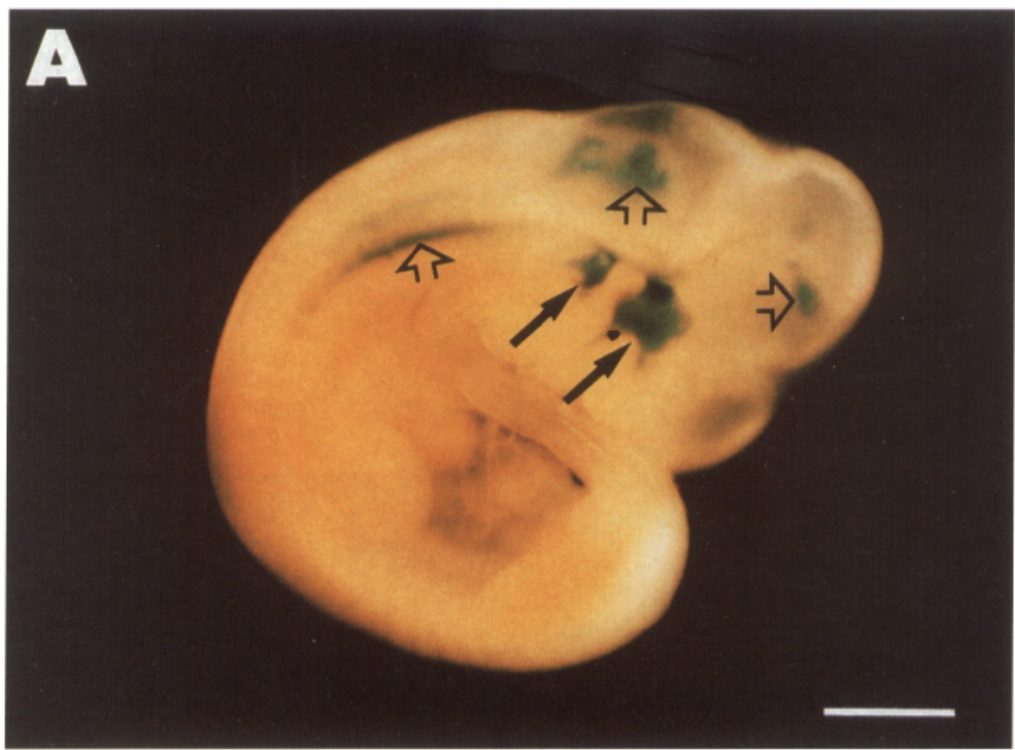

Figure 4. Expression of the transgene in embryos. $A$, Whole-mounts revealing the earliest onset of $\beta$-galactosidase activity in line 150 , at E10.5, in cranial ganglia (solid arrows) and in ventral portions of the anterior spinal cord, brainstem, and midbrain (open arrows). This line's transgene (6E11) includes 6 $\mathrm{kb}$ of $5^{\prime}$-flanking and $11 \mathrm{~kb}$ of the first intron of GAP-43. B, At E12.5, neurons within all DRG (arrows), throughout the spinal cord, and in ventral parts of all brain vesicles express the transgene. Scale bars: $A, 1 \mathrm{~mm} ; B, 2 \mathrm{~mm}$.

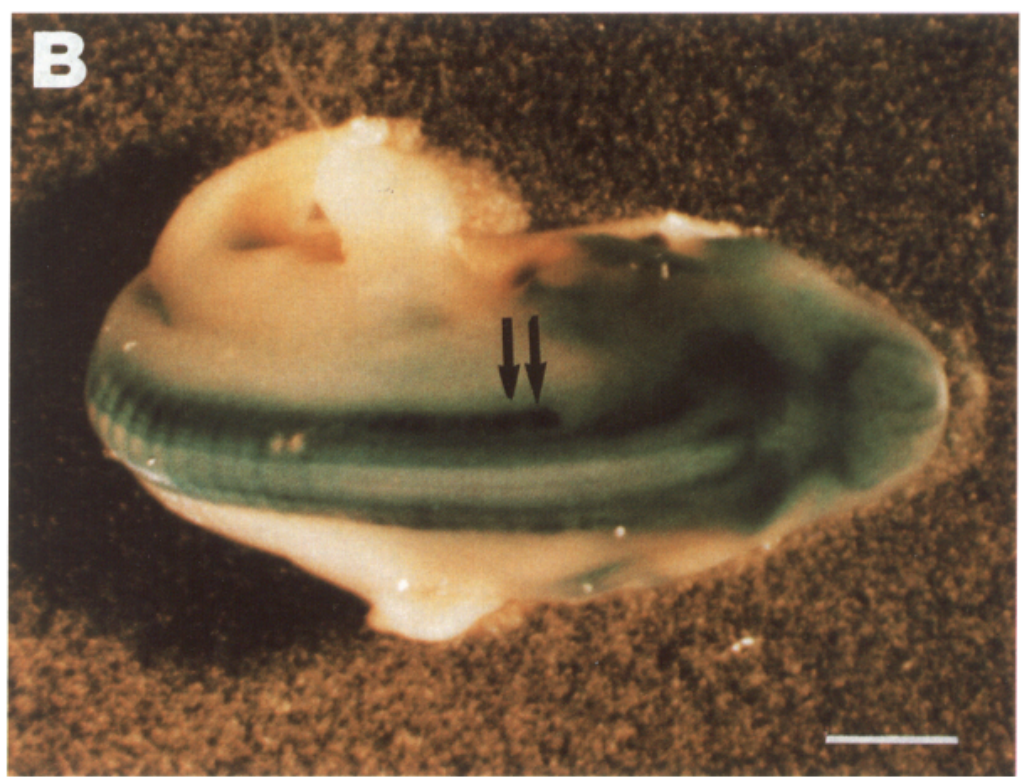

Table 1, because high levels in a few cells as revealed histologically may be diluted by nonexpressing tissue when extracted for RNA. For example, for line 526, in RNase protection there are lower levels of the protected 380 base fragment in skin and liver than in brain; Table 1 shows that subpopulations of cells of these tissues expressed the transgene at levels nearly as high as cells of the brain. Figure 2 also shows the patchiness of $\beta$-galactosidase expression when expressed in many of the non-neuronal tissues.
The pattern of transgenic expression resembles $G A P-43$

We examined line 150 (a $6 \mathrm{E} 11$ line, with $6 \mathrm{~kb} \mathrm{5}$ and $11 \mathrm{~kb}$ of intron 1) in more detail because preliminary observations suggested that its expression resembled the pattern of GAP-43 expression. Relative levels of $\beta$-galactosidase expression were carefully analyzed in several regions of the CNS and PNS, as shown in Table 2. We examined these regions at several developmental stages.

Figure 5. Transgene expression in various regions of the nervous system of line 150 in the early postnatal period. $A$, Horizontal section through the olfactory bulb at P14. Strongly positive neurons are located in the anterior olfactory nucleus (open arrow) and throughout the mitral cell layer (solid arrow). B, A detail from $A$ at higher magnification. The arrow indicates the same region as in $A$. The glomerular layer and internal granule layer are already almost free of expressing neurons. Several neurons located within the layer of tufted cells show $\beta$-galactosidase. The strongest staining is in neurons of the mitral cell layer. $C$, Within the retina at P7 all neurons of the ganglion cell layer strongly express the transgene. Some positive cells are in a sublayer of the inner nuclear layer. D. Cross section through the spinal cord (open arrow), DRG (straight solid arrows), and the sympathetic chain (curved arrow) at P14. Spinal neurons still show considerable expression at this stage. All neurons located both in the DRG and in the ganglia of the sympathetic chain are strongly positive. $g c l$, ganglion cell layer; $g l$, glomerular layer; $g r$, internal granule layer; $i n l$, inner nuclear layer; le, lens; $p e$, pigmented epithelium; $t u$, tufted cells. Scale bars: $A$ and $D, 500 \mu \mathrm{m} ; B$ and $C, 100 \mu \mathrm{m}$. 

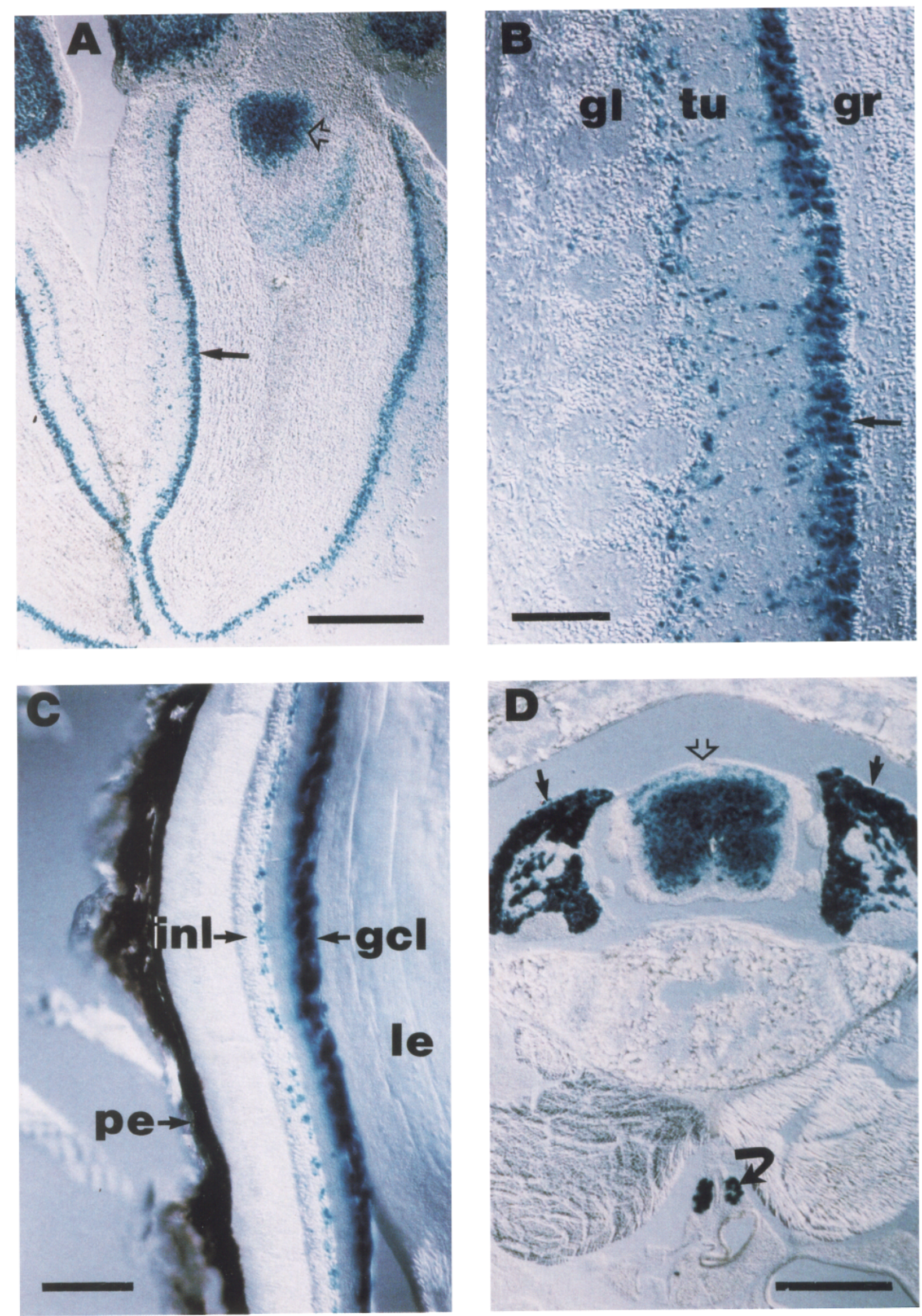
Table 2. Expression of $\beta$-galactosidase in the nervous system of line 150

\begin{tabular}{|c|c|c|c|c|c|c|}
\hline & E15.5 & $\mathrm{P} 0$ & P7 & P14 & P30 & Adult \\
\hline Cerebral cortex & $\mathrm{x}$ & $\mathbf{x x x}$ & $\operatorname{xxxxx}$ & $\operatorname{xxxx}$ & $\mathbf{x x x}$ & $\mathrm{xx}$ \\
\hline \multicolumn{7}{|l|}{ Hippocampus } \\
\hline CA1-CA4 & $\mathrm{xxx}$ & $\mathrm{xxx}$ & $\operatorname{xxxXxx}$ & $\operatorname{xxxxx}$ & $\mathrm{xxx}$ & $\mathrm{xxx}$ \\
\hline $\mathrm{DG}$ & - & - & $\mathrm{xx}$ & $\mathrm{x}$ & $x$ & - \\
\hline Subicular complex & - & $\mathrm{xxx}$ & $\operatorname{xxxxxx}$ & $\operatorname{xxxxxx}$ & $\mathrm{xxx}$ & $x x x$ \\
\hline \multicolumn{7}{|l|}{ Olfactory bulb } \\
\hline Anterior olfactory $n$. & - & - & $\operatorname{xxxxx}$ & $\operatorname{xxxx}$ & $\mathrm{xx}$ & $x x$ \\
\hline Glomerular layer & - & - & $\mathrm{x}$ & $\mathrm{x}$ & - & - \\
\hline Mitral cell layer & $\mathbf{x x x x}$ & $\operatorname{xxxxx}$ & $\operatorname{xxxxx}$ & $x x x$ & $\mathbf{x x}$ & $\mathbf{x x}$ \\
\hline Tufted cells & - & - & $\mathbf{x x x}$ & $\mathbf{x x}$ & $\mathrm{x}$ & $\mathrm{x}$ \\
\hline Caudate-putamen & - & $\mathbf{x x}$ & $\mathbf{x x}$ & $\mathbf{x x}$ & $\mathrm{x}$ & $\mathrm{x}$ \\
\hline \multicolumn{7}{|l|}{ Retina } \\
\hline GCL & $x x x x$ & $\operatorname{xxxxx}$ & $\operatorname{xxxxxx}$ & $\mathrm{xxxxx}$ & $\mathrm{xx}$ & $\mathrm{xx}$ \\
\hline INL & - & - & $\mathrm{xx}$ & $\mathrm{x}$ & $\mathbf{x}$ & $\mathrm{x}$ \\
\hline ONL & - & - & - & - & - & - \\
\hline Colliculi & $\mathrm{x}$ & $\mathrm{xx}$ & $x \times x x x$ & $\mathbf{x x x x}$ & $\mathrm{xx}$ & $\mathrm{xx}$ \\
\hline \multicolumn{7}{|l|}{ Cerebellum } \\
\hline Granular cells & - & - & $\mathbf{x x}$ & $\mathrm{xx}$ & $\mathrm{x}$ & - \\
\hline Deep cerebellar $n$. & - & - & $x x x x$ & $\operatorname{xxxx}$ & $\mathbf{x x}$ & $\mathrm{x}$ \\
\hline Molecular layer & - & - & $\mathrm{x}$ & $\mathrm{x}$ & $\mathbf{x}$ & - \\
\hline Purkinje cells & $x x x$ & $\mathbf{x x x}$ & $\mathbf{x x x x}$ & $\operatorname{xxxxx}$ & $x x$ & $\mathrm{x}$ \\
\hline Brainstem & $\mathrm{xxx}$ & $\operatorname{xxxxx}$ & $\operatorname{xxxx}$ & $\mathrm{xxx}$ & $\mathrm{x}$ & $\mathbf{x}$ \\
\hline Spinal cord & $\mathrm{xx}$ & $\operatorname{xxxx}$ & $\operatorname{xxxx}$ & $x x x$ & $x$ & - \\
\hline $\mathrm{DRG}$ & $\operatorname{xxxxx}$ & $\operatorname{xxxxxx}$ & $\operatorname{xxxxx}$ & $\operatorname{xxxx}$ & $x x x$ & $x x$ \\
\hline Sympathetic chain & $\mathrm{xxx}$ & $\operatorname{xxxx}$ & $\operatorname{xxxxx}$ & $\mathbf{x x x x x}$ & $\mathbf{x x x}$ & $\mathbf{x x}$ \\
\hline
\end{tabular}

For this estimation, cryostat sections of animals of line 150 (construction 6E11) were developed under identical conditions, and for identical times, and evaluated using the following expanded scale: -, almost no positive cells; $x$, less than half of the cells weakly stained (staining often in small vesicles); $x x$, majority of cells weakly stained (staining in small vesicles); $\mathrm{xxx}$, majority of cells moderately stained (staining in large dark blue vesicles) or almost all cells weakly stained; $x x x x$, almost all cells stained (staining in large dark blue vesicles); $x x x x x$, almost all cells strongly stained (cell bodies uniformly

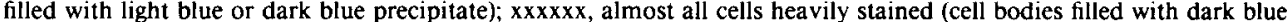
precipitate, proximal cellular processes stained). DG, dentate gyrus; n., nucleus; GCL, ganglion cell layer; INL, inner nuclear layer; ONL, outer nuclear layer.

During development, $\beta$-galactosidase labeling first becomes evident at E10.5, as shown using whole-mount staining in Figure 4. At this time there is substantial $\beta$-galactosidase staining in cranial ganglia, and in the ventral midbrain, brainstem, and anterior spinal cord. By E12.5 expression is more widespread, and includes all dorsal root ganglia (DRG), the entire rostrocaudal extent of the spinal cord, and ventral portions of the brain. In the cerebral cortex at E15.5, positive cells are mainly found adjacent to the olfactory bulb and hippocampal formation. By the day of birth, labeled cells are found throughout the cortex. Expression peaks at P7. At this stage virtually all cortical neurons express the transgene.

After P7, the intensity diminishes until adulthood. Restriction to subpopulations of neurons begins to become evident shortly after birth, for example, in the olfactory bulb, mostly to the mitral cells (Fig. $5 A, B$ ), and in the retina to the ganglion cells, whereas in the DRG and sympathetics, staining still is uniform. The rate of decline of $\beta$-galactosidase expression in the cortex appears to be slower than that observed by Basi et al. (1987) for native GAP-43. This could be due to differences in regulation, or to a higher stability of the bacterial protein $\beta$-galactosidase in eukaryotic cells. In several regions of the nervous system, especially the brainstem and spinal cord, $\beta$-galactosidase activity is expressed only during a brief temporal window (see Table 2), and in several others it persists in the adult. For ex- ample, in the adult olfactory bulb, considerable $\beta$-galactosidasc activity continues to be associated with neurons of the mitral cell layer, as is native GAP-43 mRNA in the rat (De la Monte et al., 1989).

The hippocampus is a region where there has been much focused interest concerning possible roles of GAP-43 in synaptic plasticity (Benowitz and Routtenberg, 1987). The developmental regulation and spatial distribution of transgene expression within this region is shown in Figure 6. As in neighboring cortical areas, the transgene shows highest expression about 1 week after birth (Fig. 6C) and reaches its adult level several weeks later. Within the adult hippocampus (Fig. 6D), CA1, CA2, CA3, and CA4 contain many robustly positive pyramidal cells, as do the neighboring entorhinal cortex and subicular complex, whereas the dentate contains only a few scattered positive neurons.

\section{Regeneration enhances transgene expression}

The expression of GAP-43 is induced in certain adult neurons during regeneration (Skene and Willard, $1981 \mathrm{~b}$; Van der Zee et al., 1989; Woolf et al., 1990). Since the developmental profile suggests that growth-regulatory elements are included in these constructions, we evaluated the regeneration responsiveness of the gene in line 150. One sciatic nerve was crushed, and the DRG and spinal cord of lumbar and posterior thoracic regions of three operated animals were examined between 4 and $15 \mathrm{~d}$ 
later. In all of these animals, $\beta$-galactosidase expression incrcases markedly in the soma of the regenerating nerves. Within the spinal cord, the increase is restricted to a population of motor neurons that are located in the ventral horn of lumbar segments 1,2 , and 3 on the injured side (Fig. $7 A$ ). In the DRG of lumbar segments 4 and 5 there is also an increase, but it is less dramatic in appearance because the basal level of expression is higher.

These experiments were also done with three animals of a transgenic line carrying the other neuron-specific construction (line 158; construction 1.6E12). As in line 150, strong induction of $\beta$-galactosidase is evident in motor neurons of lumbar segments 1, 2, and 3 on the operated side (Fig. $7 B$ ). As shown in Figure $7 C$, in these animals basal DRG expression is low, so that, as shown in Figure $7 D$, the regeneration-induced increase is clear.

\section{Discussion}

The combination of GAP-43 5'-flanking sequence with $11 \mathrm{~kb}$ of intron 1 is capable of conferring nervous system-specific expression upon $\beta$-galactosidase. The transgene becomes activated during embryogenesis at about the same time and within the same regions as does the endogenous GAP-43 gene (cf. Biffo et al., 1990), and diminishes after the peak time of neuronal growth. As is true for GAP-43, adult expression of the transgene continues in particular subpopulations of neurons. This suggests that the complex pattern of GAP-43 RNA expression is mediated by elements included within this region of the genome.

Even with line 150 there are some subtle differences between the pattern of transgene expression and that of GAP-43 RNA, at least as the latter has been evaluated in the rat. For example, both the transgene and GAP-43 are expressed in CA1, CA2, and $C A 3$, but, in the rat, CA3 contains relatively more GAP43 than does CA1 (Meberg and Routtenberg, 1991), whereas the transgene is expressed at comparable levels in CA 1 and CA3. Some of the differences may be due to differences in stability and subcellular distribution between $\beta$-galactosidase and GAP43. In addition, there may be a distinction in GAP-43 distribution between mouse and rat. In fact, as opposed to the rat, in the mouse the levels of GAP-43 expression in CA1 and CA3 are comparable (P. J. Meberg and $\Lambda$. Routtenberg, personal communication). It is also possible that the transgene is not regulated identically to native GAP-43 in all regards.

Regulation of transcription initiation is the most straightforward and most likely mechanism by which these elements could exert control. RNA stability can, at least in PC12 cells, play a role in regulation of GAP-43 levels (Perrone-Bizzozero et al., 1993), but is not likely to the primary determinant of neuronal specificity because all of the constructs that included intron, whether neuron specific or not, generated the same spliced product. We have not formally ruled out alternative splicing or transcriptional termination within the intron as contributing factors.

All of these transgene constructions include a minimum of $1.6 \mathrm{~kb}$ upstream of the initiating methionine, which is well $5^{\prime}$ of all proposed initiation sites. Both primer extension and RNase protection agree that there are multiple sites of RNA initiation (Grabczyk et al., 1990), but an argument has been made for one of the longer transcripts, starting about $460 \mathrm{bp}$ upstream of the ATG translation start site, being the principle one (Nedevi et al., 1992). All of these transgenes cause expression in the nervous system, but even up to $10 \mathrm{~kb}$ of 5 -flanking sequence is insufficient to restrict expression to neurons in the absence of sequences between $4 \mathrm{~kb}$ and $11 \mathrm{~kb}$ in the first intron. Since all constructions are expressed in neurons, it is likely that these $5^{\prime}$ flanking regions contain positive elements, with regard to neuronal expression. Transgene expression in non-neuronal tissue occurs with two different intron deletions, as well as with no intron at all, indicating that it is not an artifact due to new sequences conferred at junction sites within the construction. The inclusion of generic introns tends to increase the level of transgene expression in transgenic mice (Brinster et al., 1988; Choi et al., 1991; Palmiter et al., 1991), but this alone is unlikely to explain the findings reported here because four of the constructions, even those without neuronal specificity, include large portions of the intron (including the splice donor and acceptor sites), and mice with an intronless construction do not show lower expression levels generally, but rather shift locales of expression. Therefore, it is likely that the intron sequence serves to suppress expression in non-neuronal tissues. Suppression as a means to restrict expression has been demonstratcd in transgenic mice, for example, with the gene SCG10 (Wuenschell et al., 1990).

Regulatory elements that drive neuron-specific expression in transgenic animals have been described for several genes, including those for the amyloid precursor protein (Wirak et al., 1991), neurofilament (Julien et al., 1987), Purkinje cell-specific protein 2 (Oberdick et al., 1990; Vandaele et al., 1991), olfactory marker protein (Danciger et al., 1989), neuron-specific enolase (Forss-Petter et al., 1990), rhodopsin (Lem et al., 1991; Zack et al., 1991), and dopamine $\beta$-hydroxylase (Mercer et al., 1991). No specific sequences have been identified that cause neuronal expression, although the responsible elements described all reside in the 5 -flanking region and do include some sequence similarities (Vandaele et al., 1991).

Although in many cases elements that cause tissue specificity appear to reside in the $5^{\prime}$-flanking region of a gene, a role also has been noted for cis-acting elements in the introns. For example, the Thy-1 gene has elements responsible for brain, thymus, kidney, and spleen expression, and all are separate and all are downstream of transcription initiation, including the brainspecific element that is in the first intron (Vidal et al., 1990).

The overall levels of transgene expression are much lower than that of cndogenous GAP-43 and are subject to chromosomal position effects. This suggests that these constructions may lack a dominant regulatory region, as has been found for the globin gene family. A region roughly $50 \mathrm{~kb}$ upstream of the globin gene cluster is essential for position-independent expression of transgenes at a level per copy that approximates that of the endogenous gene (Grosveld et al., 1987; Reitman et al., 1990). Hence, it is quite conceivable that other elements serve to increase the level of neuronal expression, in addition to those regions we have found to suppress it in non-neuronal cells. As noted above, the constructions lacking the suppressor sequences within the intron still have a propensity to be expressed in the brain, suggesting that the promoter region, or the proximal end of the intron, might contribute heightened expression in the nervous system. This would be compatible with the suggestion by Nedevi et al. (1992), based on transfection in culture, that 5 ' GAP-43 elements confer greater expression in neurons.

Certain neurons are capable of regenerating their axons after injury, and this is accompanied by a substantial change in a particular set of axonally transported growth-associated proteins (GAPs), of which GAP-43 is one (Skene and Willard, 1981b). It has been suggested that this class of proteins is necessary for regenerative axonal growth. During regeneration, GAP-43 in- 

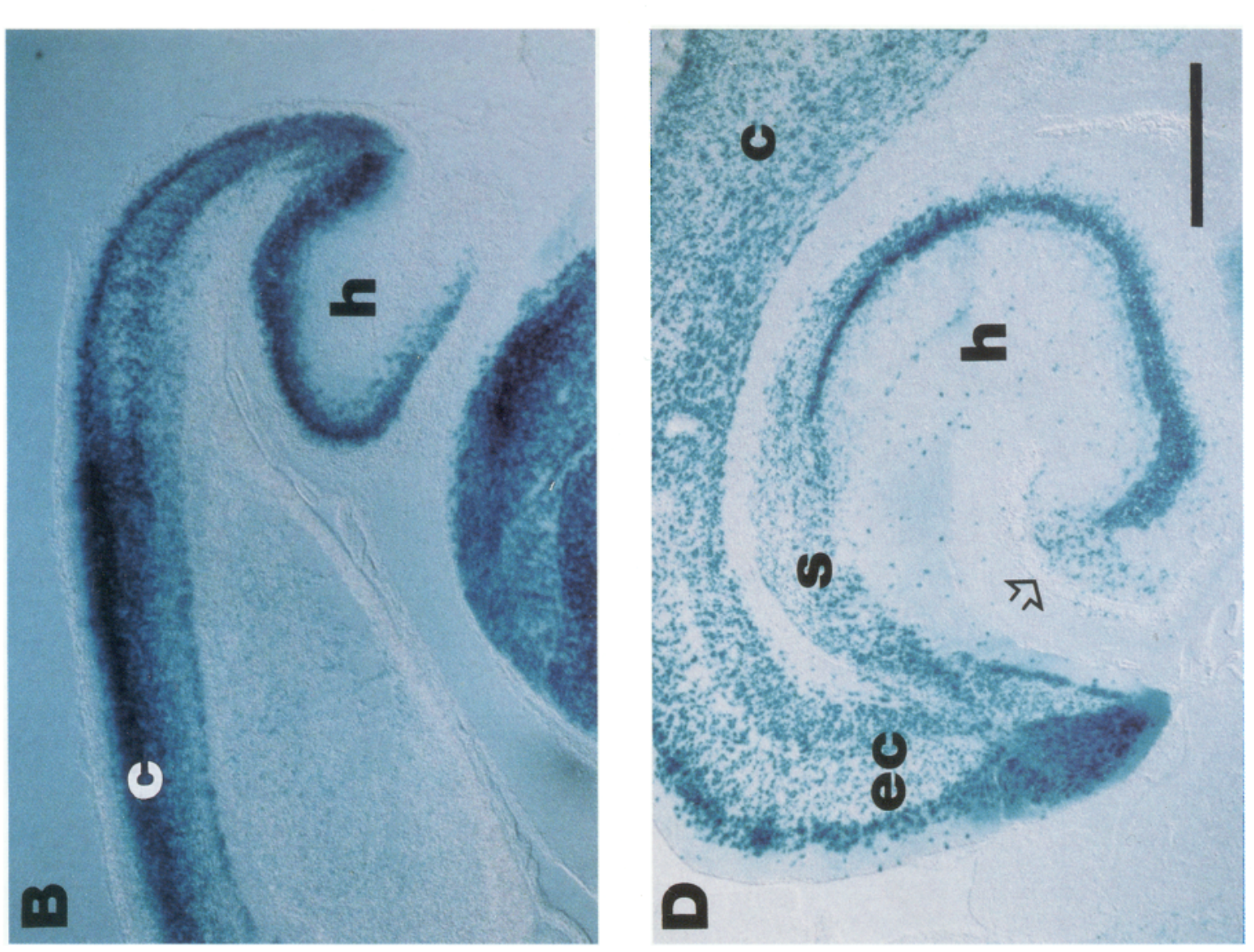

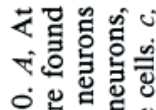

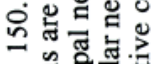

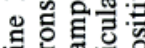

要

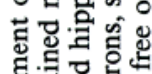

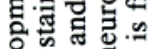

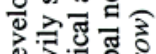

o

등

แิธิสี ํำ

뽕

t.

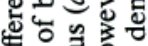

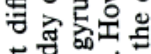

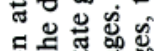

要焉焉

的论

원

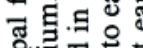

룽

응

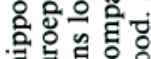

羊

월

ฮु

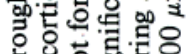

t5 형.

ด ¿

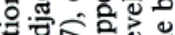

和证 可氠骂

0

(b)

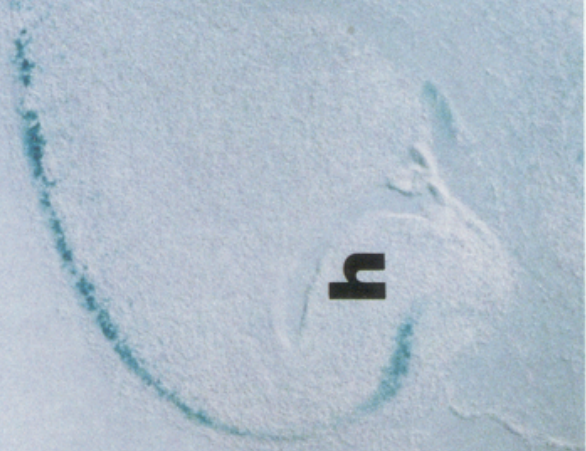

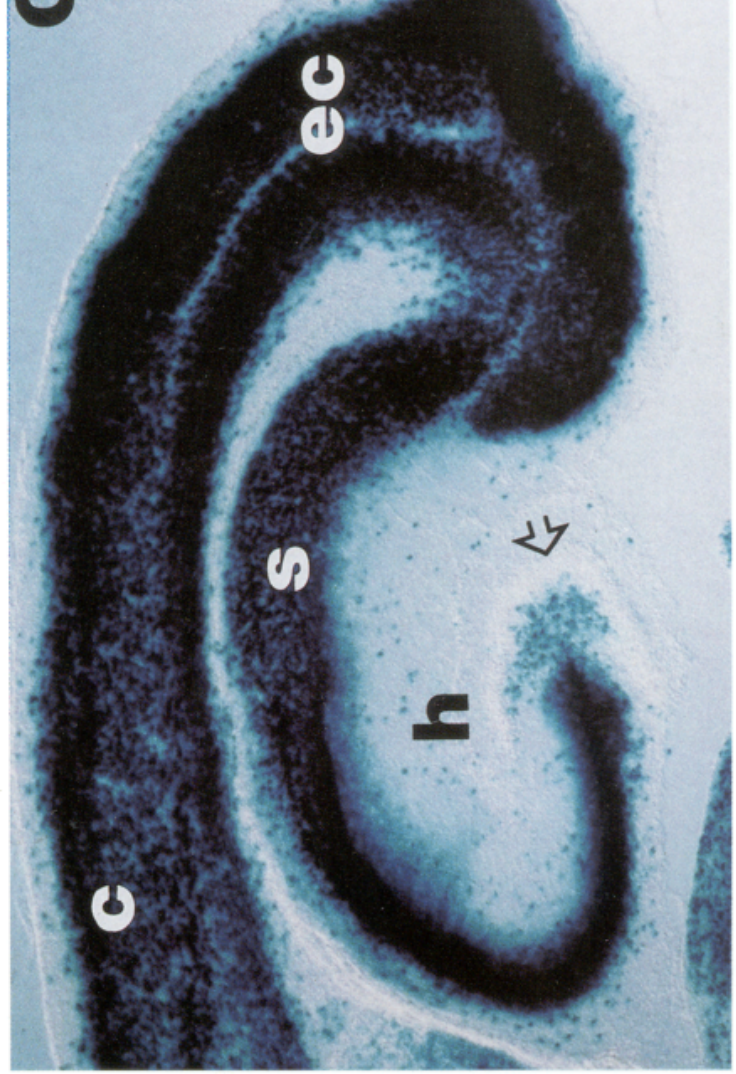

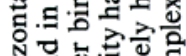

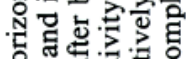
需 总象苋出 E 등ㅇㅇㅇㅇㅇ 政的 亭政 政

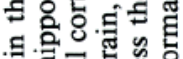
․ㅡ열

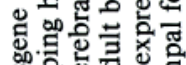

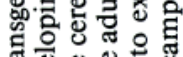

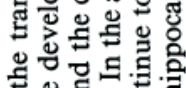
论

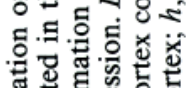

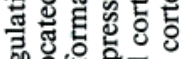

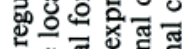

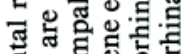
氜在品 o 웡 을 웡

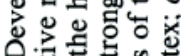
帘 क

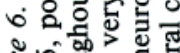

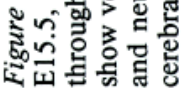



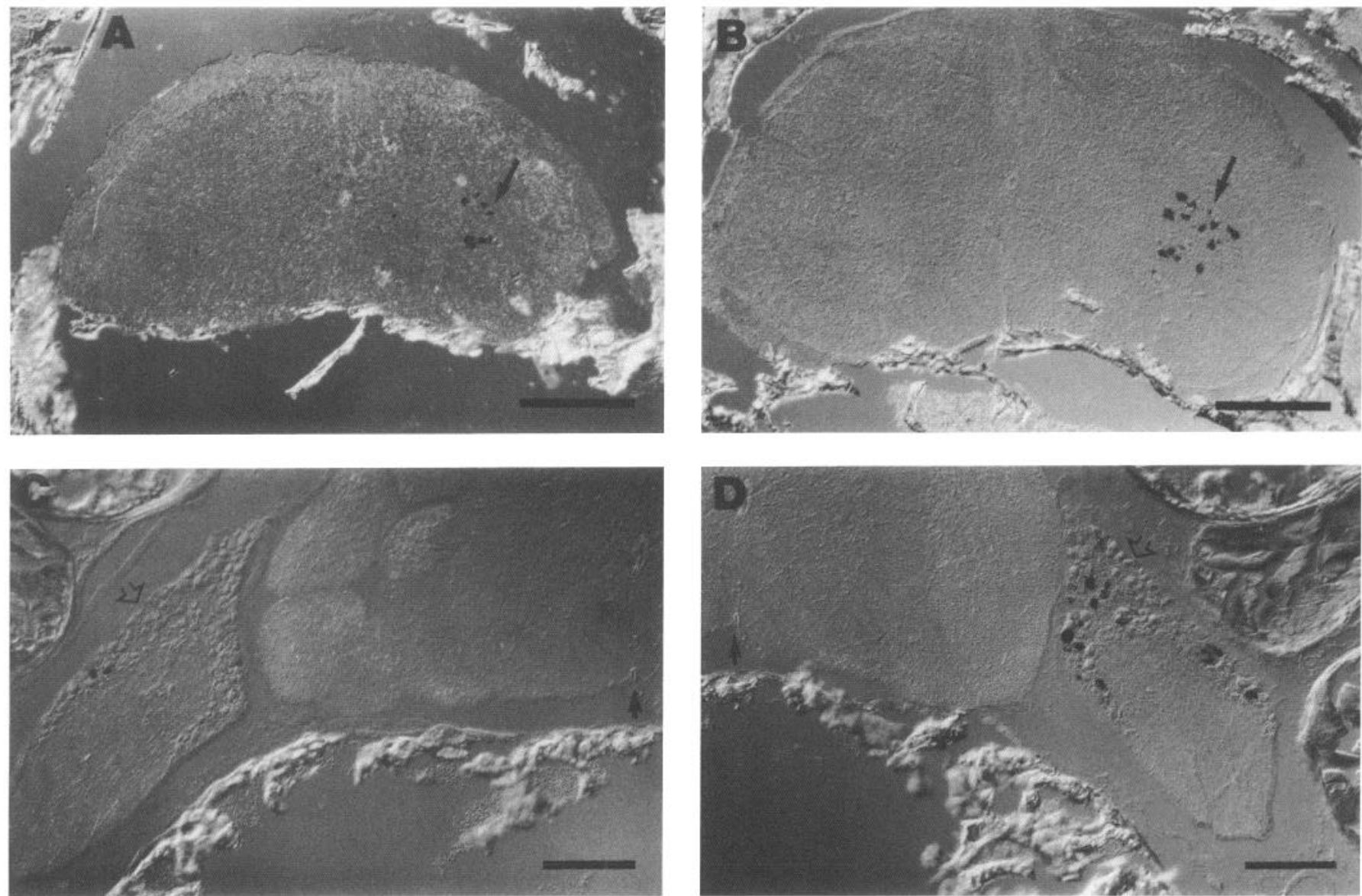

Figure 7. Regeneration-induced transgene expression in spinal motor neurons and sensory neurons: cross sections through the lumbar spinal cord of adult animals after sciatic nerve crush. $A$ and $B$, Mouse of line $150(6 \mathrm{E} 11), 15 \mathrm{~d}$ after sciatic nerve crush $(A)$, and mouse of line 158 (1.6E12), $10 \mathrm{~d}$ after crush $(B)$. Strongly expressing motor neurons (arrows) are located in the ventral horn of the injured side in both $A$ and $B$, whereas on the control side in both cases, no cells express above background levels. The level of the section is at lumbar segment 2 in $A$ and lumbar segment 1 in $B$. C and D. Cross section through the spinal cord (solid arrows) and DRG (open arrows) of lumbar segment four of an adult animal of line $1587 \mathrm{~d}$ after the left sciatic nerve was crushed. In the DRG of the control side $(C)$ only occasional cells are found to be positive. However, within the DRG of the operated side $(D)$, many neurons show considerable transgene expression. (Motor neurons at this level do not project into the sciatic nerve, so do not evidence increased expression.) Scale bars: $A$ and $B, 500 \mu \mathrm{m} ; C$ and $D, 200 \mu \mathrm{m}$.

creases, both as axonally transported protein (Skene and Willard, 1981b; Skene et al., 1986) and as RNA (Hoffman, 1989). The strong induction of $\beta$-galactosidase in regenerating motor neurons and sensory neurons of line 150 demonstrates that its transgene includes elements responsive to the stimulus that causes regeneration. This is not to suggest that the elements causing developmental increases in GAP-43, which accompany normal axonogenesis, necessarily are identical to those that respond during regeneration, especially since the signals from the microenvironment of the developing as opposed to regenerating growth cone may be distinct.

\section{References}

Al Shawi R, Kinnaird J, Burke J, Bishop JO (1990) Expression of a foreign gene in a line of transgenic mice is modulated by a chromosomal position effect. Mol Cell Biol 10:1192-1198.

Alexander KA, Cimler BM, Meier KE, Storm DR (1987) Regulation of calmodulin binding to P-57, a neurospecific calmodulin binding protein. J Biol Chem 262:6108-6113.

Allen ND, Keverne EB, Surani MA (1990) A position-dependent transgene reveals patterns of gene expression in the developing brain. Dev Brain Res 55:181-190.

Baetscher M, Schmidt E, Shimizu A, Leder P, Fishman MC

$(1991)$
SV 40 antigen transforms calcitonin cells of the thyroid but not CGRPcontaining neurons in transgenic mice. Oncogene 6:1133-1138.

Bailey CH, Chen M (1988) Long-term sensitization in Aplysia increases the number of presynaptic contacts onto the identified gill motor neuron L7. Proc Natl Acad Sci USA 85:9356-9359.

Basi GS, Jacobson RD, Virág I, Schilling J, Skene JHP (1987) Primary structure and transcriptional regulation of GAP-43 a protein associated with nerve growth. Cell 49:785-791.

Bendotti C, Servadio A, Samanin R (1991) Distribution of GAP-43 mRNA in the brain stem of adult rats as evidenced by in situ hybridization: localization within monoaminergic neurons. J Neurosci 11:600-607.

Benowitz LI, Routtenberg A (1987) A membrane phosphoprotein associated with neural development, axonal regeneration, phospholipid metabolism, and synaptic plasticity. Trends Neurosci 10:527532.

Benowitz LI, Apostolides PJ, Perrone-Bizzozero N, Finklestein SP, Zwiers $\mathrm{H}$ (1988) Anatomical distribution of the growth-associated protein GAP-43/B50 in the adult rat brain. J Neurosci 8:339-352.

Biffo S, Verhaagen J, Schrama LH, Schotman P, Danho W, Margolis FL (1990) B50/GAP-43 expression correlates with process outgrowth in the embryonic mouse nervous system. Eur J Neurosci 2:487499.

Bonnerot C, Grimber G, Briand P, Nicolas J-F (1990) Patterns of expression of position-dependent integrated transgenes in mouse embryo. Proc Natl Acad Sci USA 87:6331-6335. 
Brinster RL, Allen JM, Behringer RR, Gelinas RE, Palmiter RD (1988) Introns increase transcriptional efficiency in transgenic mice. Proc Natl Acad Sci USA 85:836-840.

Choi T, Huang M, Gorman C, Jaenisch R (1991) A generic intron increases gene expression in transgenic mice. Mol Cell Biol 11:30703074.

Danciger E, Mettling C, Vidal M, Morris R, Margolis F (1989) Olfactory marker protein gene: its structure and olfactory neuron-specific expression in transgenic mice. Proc Natl Acad Sci USA 86:85658569.

De Graan PN, Dekker LV, De Wit M, Schrama LH, Gispen WH (1988) Modulation of B50 phosphorylation and polyphosphoinositide metabolism in synaptic plasma membranes by protein kinase $\mathrm{C}$, phorbol diesters and ACTH. J Recept Res 8:345-361.

De la Monte SM, Federoff HJ, Ng SC, Grabezyk E, Fishman MC (1989) GAP-43 gene expression during development: persistence in a distinctive set of neurons in the mature central nervous system. Dev Brain Res 46:161-168.

Dekker LV, De Graan PN, Oestreicher AB, Versteeg DH, Gispen WH (1989) Inhibition of noradrenaline release by antibodies to B50 (GAP43). Nature 342:74-76.

Federoff HJ, Grabczyk E, Fishman MC (1988) Dual regulation of GAP-43 gene expression by nerve growth factor and glucocorticoids. J Biol Chem 263:19290-19295.

Fitzgerald M, Reynolds ML, Benowitz LI (1991) GAP-43 expression in the developing rat lumbar spinal cord. Neuroscience 41:187-199.

Forss-Petter S, Danielson PE, Catsicas S, Battenberg E, Price J, Nerenberg M, Sutcliffe JG (1990) Transgenic mice expressing $\beta$-galactosidase in mature neurons under neuron-specific enolase promoter control. Neuron 5:187-197.

Grabczyk E, Zuber MX, Federoff HJ, Ng S-C, Pack A, Fishman MC (1990) Cloning and characterization of the rat gene encoding GAP43. Eur J Neurosci 2:822-827.

Grosveld F, van Assendelft GB, Greaves DR, Kollias G (1987) Position-independent, high-level expression of the human beta-globin gene in transgenic mice. Cell 51:975-985.

Hoffman PN (1989) Expression of GAP-43, a rapidly transported growth-associated protein, and class II beta tubulin, a slowly transported cytoskeletal protein, are coordinated in regenerating neurons. J Neurosci 9:893-897.

Hogan B, Constantini F, Lacey E (1986) Manipulating the mouse embryo: a laboratory manual. Cold Spring Harbor, NY: Cold Spring Harbor Laboratory.

Julien JP, Tretjakoff I, Beaudet L, Peterson A (1987) Expression and assembly of a human neurofilament protein in transgenic mice provide a novel neuronal marking system. Genes Dev 1:1085-1095.

Kapur RP, Hoyle GW, Mercer EH, Brinster RL, Palmiter RD (1991) Some neuronal cell populations express human dopamine $\beta$-hydroxylase-lac $Z$ transgenes transiently during embryonic development. Neuron 7:717-727.

Kozak M (1986a) Point mutations define a sequence flanking the AUG initiator codon that modulates translation by eukaryotic ribosomes. Cell 44:283-292.

Kozak M (1986b) Bifunctional messenger RNAs in eukaryotes. Cell $47: 481-483$.

Kozak M (1987) Effects of intercistronic length on the efficiency of reinitiation by eucaryotic ribosomes. Mol Cell Biol 7:3438-3445.

Lem J, Applebury ML, Falk JD, Flannery JG, Simon MI (1991) Tissue-specific and developmental regulation of rod opsin chimeric genes in transgenic mice. Neuron 6:201-210.

Lovinger DM, Akers RF, Nelson RB, Barnes CA, McNaughton BL, Routtenberg A (1985) A selective increase in phosphorylation of protein $F 1$, a protein kinase C substrate, directly related to three day growth of long term synaptic enhancement. Brain Res 343:137-143.

Meberg PJ, Routtenberg A (1991) Selective expression of protein F1/ (GAP)-43 mRNA in pyramidal but not granule cells of the hippocampus. Neuroscience 45:721-733.

Mercer EH, Hoyle GW, Kapur RP, Brinster RL, Palmiter RD (1991) The dopamine $\beta$-hydroxylase gene promoter directs expression of $E$. coli lacZ to sympathetic and other neurons in adult transgenic mice. Neuron 7:703-716.

Vedevi E, Basi GS, Akey IV, Skene JHP (1992) A neuronal-specific
GAP-43 corc promotcr located between unusual DNA elements that interact to regulate its activity. J Neurosci 12:691-704.

Neve RL, Perrone BNI, Finklestein S. Zwiers H, Bird E, Kurnit DM Benowitz LI (1987) The neuronal growth-associated protein GAP43 (B50, F1): neuronal specificity, developmental regulation and regional distribution of the human and rat mRNAs. Brain Res 388 : 177-183.

Oberdick J, Smeyne RJ, Mann JR, Zackson S, Morgan JI (1990) A promoter that drives transgene expression in cerebellar Purkinje and retinal bipolar neurons. Science 248:223-225.

Palmiter RD, Sandgren EP, Avarbock MR, Allen DD, Brinster RL (1991) Heterologous introns can enhance expression of transgenes in mice. Proc Natl Acad Sci USA 88:478-482.

Perrone-Bizzozero NI, Cansino VV, Kohn DT (1993) Posttranscriptional regulation of GAP-43 gene cxpression in PC12 cells through protein kinase C-dependent stabilization of the mRNA. J Cell Biol 120:1263-1270.

Reitman M, Lee E, Westphal H, Felsenfeld G (1990) Site-independent expression of the chicken beta A-globin gene in transgenic mice. Nature 348:749-752.

Rosenthal A, Chan SY, Henzel W, Haskell C, Kuang WJ, Chen E, Wilcox JN, Ullrich A, Goeddel DV, Routtenberg A (1987) Primary structure and mRNA localization of protein Fl, a growth-related protein kinase $C$ substrate associated with synaptic plasticity. EMBO J 6:3641-3646.

Skene JH, Willard M (1981a) Characteristics of growth-associated polypeptides in regenerating toad retinal ganglion cell axons. J Neurosci 1:419-426.

Skene JH, Willard M (1981b) Axonally transportcd protcins associated with axon growth in rabbit central and peripheral nervous systems. J Cell Biol 89:96-103.

Skene JH, Jacobson RD, Snipes GJ, McGuire CB, Norden JJ, Freeman JA (1986) A protein induced during nerve growth (GAP-43) is a major component of growth-cone membranes. Science 233:783-786.

Strittmatter SM, Valenzuela D, Kennedy TE, Neer EJ, Fishman MC (1990) $G_{o}$ is a major growth cone protein subject to regulation by GAP-43. Nature 344:836-841.

Tan S-S (1991) Liver specific and position-effect expression of a retinolbinding protein-lacZ fusion gene (RBP-lacZ) in transgenic mice. Dev Biol 146:24-37.

Turner DL, Cepko CL (1987) A common progenitor for neurons and glia persists in rat retina late in development. Nature 328:131-136.

Van der Zee CE, Nielander HB, Vos JP, Lopes da Silva S, Verhaagen J, Oestreicher AB, Schrama LH, Schotman P, Gispen WH (1989) Expression of growth-associated protein B50 (GAP43) in dorsal root ganglia and sciatic nerve during regenerative sprouting. $J$ Neurosci 9:3505-3512.

Vandaele S, Nordquist DT, Feddersen RM, Tretjakoff I, Peterson AC, Orr HT (1991) Purkinje cell protein-2 regulatory regions and transgene expression in cerebellar compartments. Genes Dev 5:1136-1148.

Vidal M, Morris R, Grosveld F, Spanopoulou E (1990) Tissue-specific control elements of the Thy-1 gene. EMBO J 9:833-840.

Weis J, Fine SM, David C, Savarirayan S, Sanes JR (1991) Integration site-dependent expression of a transgene reveals specialized features of cells associated with neuromuscular junctions. J Cell Biol 113: 1385-1397.

Wirak DO, Bayney R, Kundel CA, Lee A, Scangos GA, Trapp BD, Unterbeck AJ (1991) Regulatory region of human amyloid precursor protein (APP) gene promotes neuron-specific gene expression in the CNS of transgenic mice. EMBO J 10:289-296.

Woolf CJ, Reynolds ML, Molander C, O'Brien C, Lindsay RM, Benowitz LI (1990) The growth-associated protein GAP-43 appears in dorsal root ganglion cells and in the dorsal horn of the rat spinal cord following peripheral nerve injury. Neuroscience 34:465-478.

Wuenschell CW, Mori N, Anderson DJ (1990) Analysis of SCG10 gene expression in transgenic mice reveals that neural specificity is achieved through selective derepression. Neuron 4:595-602.

Zack DJ, Bennett J, Wang Y, Davenport C, Klaunberg B, Gearhart J, Nathans J (1991) 2Unusual topography of bovine rhodopsin promoter-lac $Z$ fusion gene expression in transgenic mouse retinas. Neuron 6:187-199. 